At $£ 34.95$ this is not an easily affordable book but it deserves to be widely read and used as a basis for information and discussion.

PROFESSOR T E OPPE Emeritus Professor of Paediatrics

\section{Perilous knowledge}

\section{Tom Wilkie, 195 pages, London, 1993, Faber and Faber, \$22.95, $£ 14.99$}

Perilous Knowledge is perfectly timed. Tom Wilkie's balanced discussion of the social and ethical implications of the human genome project will be welcomed by all those who are concerned by reports of gene therapy and 'gay genes'.

The book is divided into two sections. The first covers the history of molecular biology and describes how scientists have progressed from Darwin's complete ignorance of genetic material to our present-day sophistication. The second section considers the implications of the human genome project, taking a historical point of view. Wilkie wisely avoids wild speculation about future revolutions and instead examines how our limited genetic knowledge has been used and abused in the past.

Chapters 2-4 provide an introduction to molecular biology and its history. Despite its rather hyperbolic style, the text reads well and carries the flavour of the subject. Unfortunately, Wilkie's vow to avoid jargon and his seeming dislike for diagrammatic illustration will leave the uninitiated only superficially informed. We learn about the discovery of the structure and function of DNA. The concepts of genes and protein synthesis are presented with a description of some of the most closely studied single gene diseases.

The human genome is compared to a public library, each of the 46 bays representing a chromosome. The challenge of gene mapping and genome sequencing is to locate and read all the $50,000+$ meaningful volumes (the genes) in the midst of the apparent gibberish which constitutes more than 90 per cent of the library.

Some of the technical advances which underpin the genome project and the associated biotechnology industry are mentioned in a chapter that attempts to explain recombinant
DNA technology, bacterial and viral genetics, gene splicing and more. The history of molecular biology is then rounded off with a fascinating analysis of the origins and emphases of the European and American genome projects.

The second half of the book is a ramble through the potential ethical confusion which threatens to engulf a scientifically naive society. The thrust of much of the commentary is that the new knowledge will be abused, not out of malice, but out of ignorance and hysteria.

Wilkie worries that only the rich will benefit from the new knowledge and that the poor will become a genetic underclass. Darwin told us that Man is born unequal, allowing natural selection to mould us. Galton's nineteenth century eugenics sought to replace natural selection with a programme of selective breeding. Wilkie presents a modern world where genetic screening and selective termination will permit the creation of designer children.

When the future of reproduction is so cool and logical the temptation is to think of our humanity as nothing more than a biological computer programme. James Rachels is quoted as decrying conventional morality as 'speciesist' because $H$ sapiens and other animals are no longer in different moral categories. Here, surely, is the ultimate in the humbling of Man, our moral worth is nothing more than the richness and complexity of our programme.

DAMIAN C CROWTHER 22 Hengrove Close, Barton, Headington, Oxford, OX3 $9 L N$

\section{Pro-life? The Irish question}

Michael Solomons, 86 pages, Dublin, Ireland, 1992, Lilliput Press, $£ 3.95$ (Irish punts)

The title of this book is a superb choice. The question Pro-life? is deeply provocative and philosophical in its implications. Michael Solomons scrutinises what 'pro-life' means in the Republic of Ireland and does this from a position of one who has lived in Ireland all of his life. Born in Dublin in 1919, Solomons was an obstetrician-gynaecologist until his retirement in 1988 . The book was written against the background of acrimonious Irish debate about abortion which has gone on virtually uninterrupted since 1981 . This debate was intensified in 1992 when a 14-year-old rape victim was served a High Court injunction, initiated by the Attorney General, preventing her from legally travelling to England for an abortion. A society which goes to such lengths to prevent a rape victim from having an abortion might be explained by its history and Solomons's study provides a great deal of that history. In Pro-life? The Irish Question, Solomons tells the complex story of Irish policies on contraception and abortion over the last seventy years. Ireland's laws governing matters of reproduction have resulted from the interaction of religious, cultural, legal and medical institutions which have traditionally reinforced a pro-natalist viewpoint, reiterating women's 'proper moral roles' as mother and reproducer. The national hegemony of the Roman Catholic Church in the republic has provided the main institutional support for religious orthodoxy on questions of reproduction.

Abortion in Ireland has been legally prohibited under the British Offences Against the Person Act of 1861. In rare cases such as ectopic pregnancy, therapeutic abortions have been quietly tolerated in Ireland under the traditional principle of double effect. In September 1983, after two years of acrimonious public debate on abortion, a national referendum passed the Eighth Amendment to the Irish Constitution which reads: 'The State acknowledges the right to life of the unborn and, with due regard to the equal right to life of the mother, guarantees in its laws to protect, and as far as practicable, by its laws, to defend and vindicate that right.'

The ambiguities of meaning in this amendment were noted from its first publication. In debating the amendment, many voices had argued that a constitution is not a suitable mechanism for determining abortion policies within a country. Events in Ireland since 1983 have confirmed that judgement. The Irish legal ban on abortion in no way reflects the reality of abortion choice by Irish women. Since abortion became legal in Britain in 1969 , it is estimated that 5,000 women each year travel to Britain for abortions. However, this figure is almost certainly an underestimate. For many Irish women who choose abortions in England do not use an Irish address for fear of identification 